\title{
Energetics of Saddling versus Ruffling in Metalloporphyrins: Unusual Ruffled Dodecasubstituted Porphyrins
}

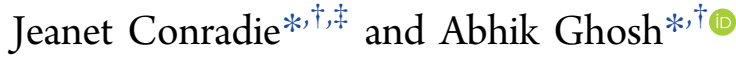 \\ ${ }^{\dagger}$ Department of Chemistry and Center for Theoretical and Computational Chemistry, UiT - The Arctic University of Norway, \\ N-9037 Tromsø, Norway \\ ${ }^{\ddagger}$ Department of Chemistry, University of the Free State, PO Box 339, 9300 Bloemfontein, Republic of South Africa
}

Supporting Information

ABSTRACT: Presented herein is a first major density functional theory (BP86/D3/STO-TZ2P) survey of the energetics of saddling versus ruffling for a wide range of dodecasubstituted metalloporphyrins with $\mathrm{M}=\mathrm{Ni}, \mathrm{Cu}, \mathrm{Zn}, \mathrm{Pd}$, and Pt. For the majority of $\mathrm{X}_{8}$ TPP (i.e., $\beta$-octasubstituted-mesotetraphenylporphyrin), the calculations indicated a clear preference for the saddled conformation, consistent with a large body of experimental data. The preference for the saddled conformation relative to the ruffled conformation was found to vary from about $\sim 0.3-0.4 \mathrm{eV}$ for $\mathrm{Me}_{8} \mathrm{TPP}$ derivatives up to 1 $\mathrm{eV}$ for $\mathrm{I}_{8} \mathrm{TPP}$ and $\left(\mathrm{CF}_{3}\right)_{8} \mathrm{TPP}$ derivatives. For $\mathrm{X}=\mathrm{Ph}$, that is, dodecaphenylporphyrins, the saddled and the ruffled conformation are almost equienergetic, with even a slight preference for the ruffled conformation in some cases. This finding provides a satisfactory explanation for the X-ray crystallographic observation of both saddled and ruffled conformations for dodecaphenylporphyrin complexes as well as for spectroscopic evidence for conformational mobility of these complexes in solution. The calculations also indicate near-equienergetic saddled and ruffled conformations for meso-tetraacetylenyltetrabenzoporphyrins, again consonant with key crystallographic findings. By and large, both the energetics and nonplanar distortions of the metalloporphyrin derivatives correlated well with the Charton and Sterimol $B_{1}$ steric parameters of the peripheral substituents.

\section{INTRODUCTION}

Despite their aromatic character, metalloporphyrins adopt a variety of nonplanar conformations such as the ruffled, saddled, domed, waved, and various intermediate conformations. ${ }^{1-3}$ These deformations result from such factors as a sterically hindered set of substituents, a coordinated atom that is too small or too large, and specific metal-porphyrin orbital interactions. Of the various deformations, ruffling and saddling are the most common. Ruffling, where the meso carbons are alternately displaced above and below the mean porphyrin plane, commonly occurs for a coordinated atom/ion that is too small for a planar porphyrin; a common example is the Ni(II) ion. ${ }^{4-8}$ Certain sterically hindered substitution patterns, such as four bulky meso substituents, also result in ruffling. mesoTetraisopropyl- ${ }^{9-11}$ and meso-tetrakis $\left(t\right.$-butyl)porphyrin ${ }^{12}$ derivatives provide good examples of such ruffled porphyrins. Saddling, where the pyrrole rings are alternately tilted above and below the mean porphyrin plane, is most commonly associated with dodecasubstituted porphyrin derivatives, where it provides relief from peripheral steric overcrowding. Interestingly, the ruffled conformation has been observed for a handful of dodecasubstituted porphyrin derivatives. Thus, Smith and co-workers reported X-ray structures for both the

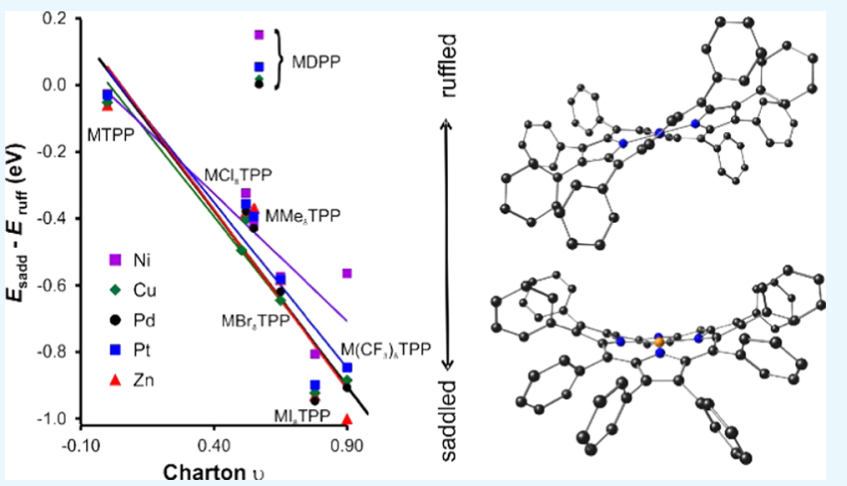

ruffled (CCDC: XAWRUI) and saddled (CCDC: TEZXEB) conformations of $\mathrm{Ni}$ dodecaphenylporphyrin ${ }^{13,14}$ and underscored the flexibility of the system. There is also significant spectroscopic evidence that $\mathrm{Ni}$ dodecaphenylporphyrin is conformationally mobile in solution. ${ }^{15}$ A ruffled conformation has been found for a Pt $\beta$-octaalkyl-meso-tetraacetylenylporphyrin (CCDC: LUTYOO, Figure 1). ${ }^{16}$ Unlike for ruffled porphyrins $^{17-19}$ and hydroporphyrins, ${ }^{20-23}$ few major quantum chemical studies have addressed the question of energetics associated with saddling in porphyrins, ${ }^{24,25}$ which has left us relatively in the dark about the relative energies of the saddled versus ruffled conformations of various dodecasubstituted metalloporphyrins. Detailed information on this subject should not only allow for a better appreciation of metalloporphyrin structural chemistry and spectroscopy ${ }^{1,2,15,25-27}$ but also stimulate the use of nonplanar porphyrins to create novel supramolecular and nanoscale structures. ${ }^{28,29}$

Prompted by the above considerations, we undertook a dispersion-corrected density functional theory (DFT) study

Received: July 17, 2017

Accepted: September 27, 2017

Published: October 13, 2017 
(a)

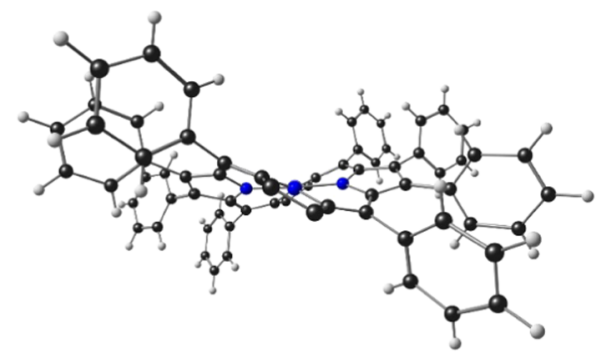

(b)

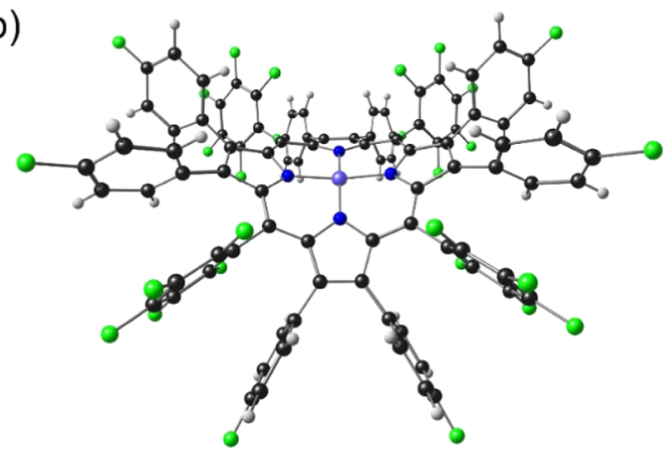

(c)

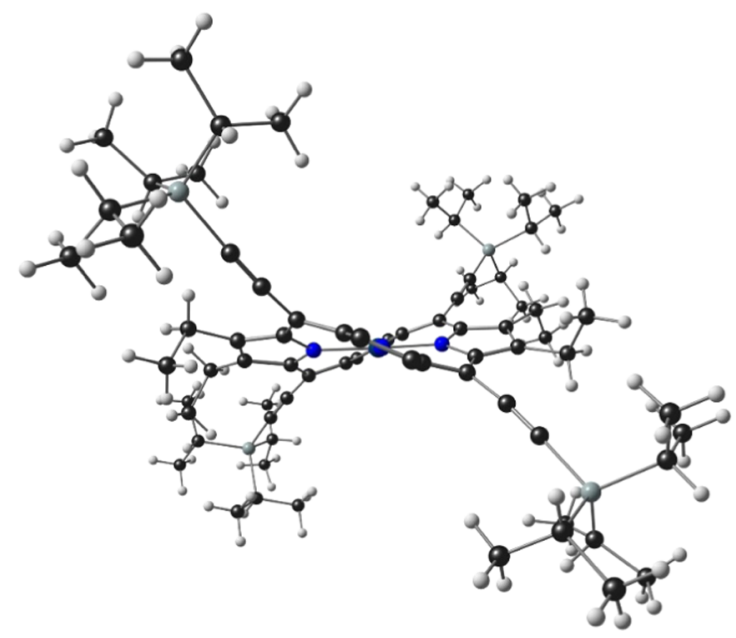

Figure 1. Representative diagrams of a (a) ruffled and (b) saddled NiDPP and (c) ruffled Pt acetylenyl porphyrins. In (a) and (c), the substituents at $\mathrm{C} 2, \mathrm{C} 3, \mathrm{C} 12$, and $\mathrm{C} 13$ have been removed for clarity.

(BP86-D3/STO-TZ2P) of a wide range of dodecasubstituted metalloporphyrins. As shown in Figure 2, three broad classes of complexes were examined (a) $\mathrm{X}_{8} \mathrm{TPP}(\mathrm{TPP}=$ tetraphenylporphyrin), where the meso substituent is phenyl and the $\beta$ substituent $\mathrm{X}=\mathrm{Me},{ }^{30-32} \mathrm{Cl}^{33-36} \mathrm{Br}^{37-39} \mathrm{Ph}^{13,14,40,41} \mathrm{I}^{42}$ and $\mathrm{CF}_{3} ;{ }^{43}$ (b) $\mathrm{Y}_{4} \mathrm{TBP}(\mathrm{TBP}=$ tetrabenzoporphyrin), where the meso substituent $\mathrm{Y}=\mathrm{C} \equiv \mathrm{C}-\mathrm{SiMe}_{3}$ (hereafter abbreviated as $\mathrm{A}$ ) and $\mathrm{Ph}^{44-47}$ and (c) $\mathrm{X}_{8} \mathrm{TAP}$ (TAP = meso-tetrakis(trimethylsilylacetylenyl)porphyrin), where $\mathrm{X}=\mathrm{Me}^{16}$ and $\mathrm{Br}$. For each porphyrin ligand, five different divalent metals were examined, namely, $\mathrm{Ni}^{13,14,16,35,36,38,39,42,43,45,46} \mathrm{Cu}^{33,38,40,42,44}$ $\mathrm{Zn},{ }^{13,34,37,41} \mathrm{Pd}$, and $\mathrm{Pt}^{16,47}$ For each metalloporphyrin, the ruffled and saddled conformations were optimized. Table 1 lists various geometry parameters and the energy difference between the saddled and ruffled conformations $\left(E_{\text {sadd }}-E_{\text {ruff }}\right)$. The key geometry parameters of interest are the ruffling $(\psi)$ and saddling dihedrals $(\chi)$, defined in Figure 3 , and the out-of-plane displacements of meso $\left(z_{\text {meso }}\right), \alpha\left(z_{\alpha}\right)$, and $\beta\left(z_{\beta}\right)$ carbons.

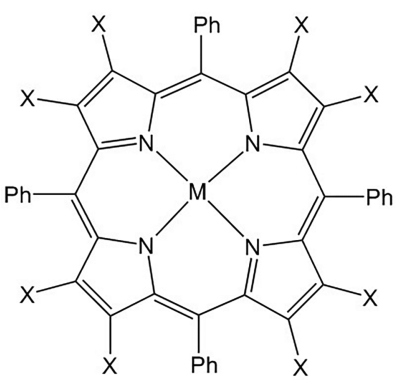

$\mathrm{X}_{8} \mathrm{TPP}, \mathrm{X}=\mathrm{H}, \mathrm{I}, \mathrm{Br}, \mathrm{Cl}, \mathrm{Me}, \mathrm{CF}_{3}, \mathrm{Ph}$

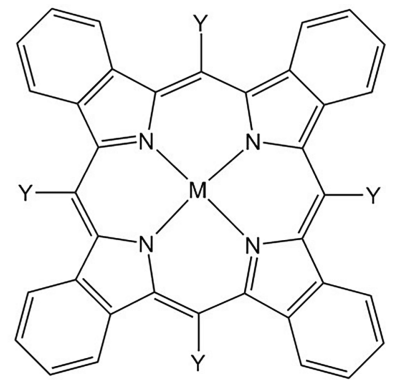

$\mathrm{Y}_{4} \mathrm{TBP}, \mathrm{Y}=\mathrm{CCSiMe}_{3} \mathrm{Ph}$

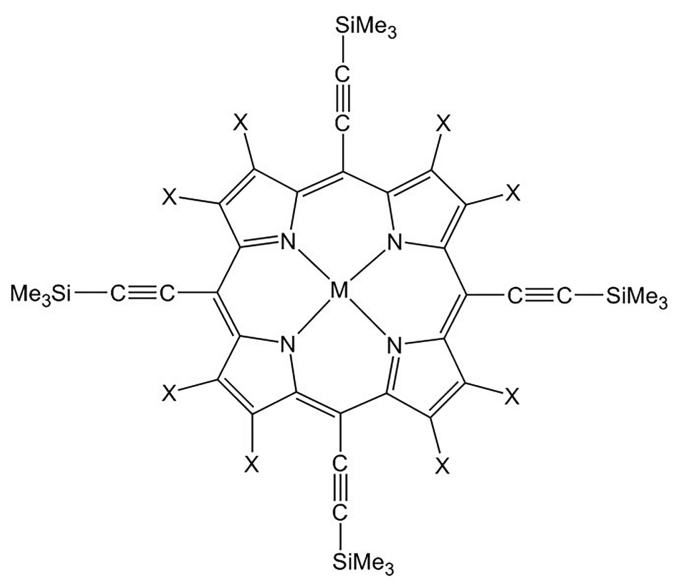

$\mathrm{X}_{8} \mathrm{TAP}, \mathrm{X}=\mathrm{Me}, \mathrm{Br}$

Figure 2. Molecules studied in this work.

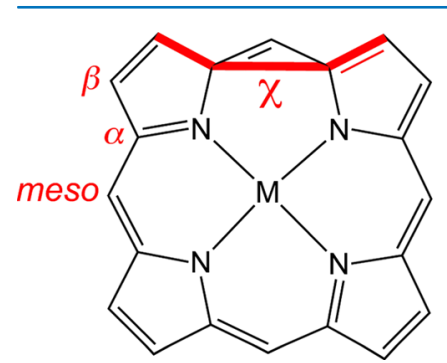

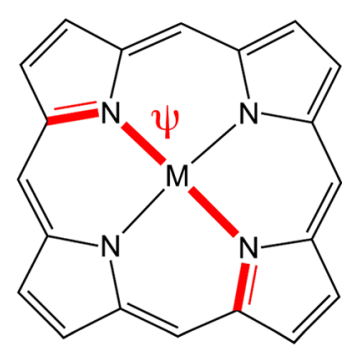

Figure 3. Definition of ruffling $(\chi)$ and saddling $(\psi)$ dihedrals.

\section{RESULTS AND DISCUSSION}

Table 1 shows that the majority of the complexes prefer a saddled conformation by a clear margin of energy, consistent with the large body of available crystallographic data. ${ }^{1}$ Also, as shown in Figure 4, with the possible exception of $\mathrm{Ni}(\mathrm{II})$, the smallest metal ion considered, $E_{\text {sadd }}-E_{\text {ruff }}$ is essentially independent of the metal, for the metal ions considered.

For the $\mathrm{X}_{8} \mathrm{TPP}$ complexes and for a given metal ion, $E_{\text {sadd }}-$ $E_{\text {ruff }}$ exhibits a strong, linear dependence on the steric bulk of the $\beta$ substituent $\mathrm{X}$, as measured by either the Charton ${ }^{48-51}$ or the Sterimol $\mathrm{B}_{1}{ }^{52-57}$ parameters (Figure 5), with one key exception, $X=P h$. Thus, the preference for the saddled conformation relative to the ruffled conformation ranges from about $\sim 0.3-0.4 \mathrm{eV}$ for $\mathrm{Me}_{8} \mathrm{TPP}$ derivatives up to $1 \mathrm{eV}$ for $\mathrm{I}_{8} \mathrm{TPP}$ and $\left(\mathrm{CF}_{3}\right)_{8} \mathrm{TPP}$ derivatives. Interestingly, for $\mathrm{X}=\mathrm{Ph}$, that is, dodecaphenylporphyrins, the saddled and the ruffled 


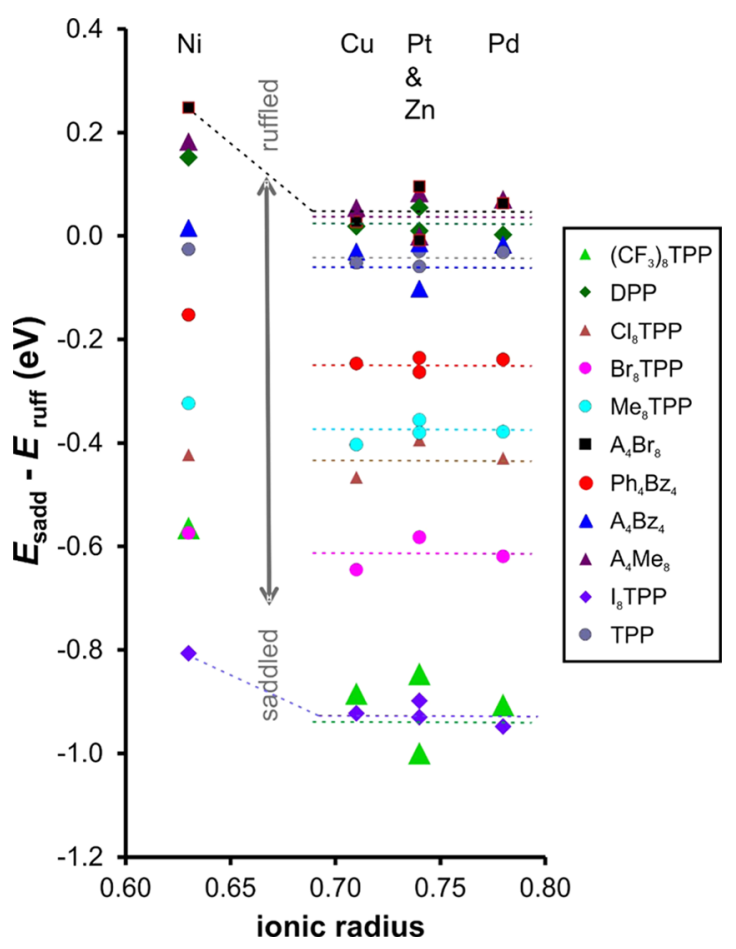

Figure 4. Energy difference $(\mathrm{eV})$ between saddled and ruffled conformations as a function of metal ion ionic radius. Ionic radii

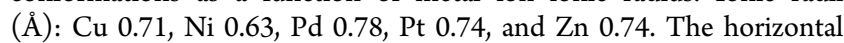
dotted lines represent the average value off $E_{\text {sadd }}-E_{\text {ruff }}$ for $\mathrm{Cu}, \mathrm{Pt}, \mathrm{Zn}$, and $\mathrm{Pd}$, underscoring that only $\mathrm{Ni}$ deviates significantly from this value.

conformations are almost equienergetic, with even a slight preference for the ruffled conformation in some cases. In other words, the phenyl groups in dodecaphenylporphyrins exert a much lower steric effect than that implied by their Charton and Sterimol $B_{1}$ parameters. The anomalously low steric effects of the phenyl groups are most reasonably ascribed to the manner in which they stack in a circular arrangement around the porphyrin periphery. These results explain the experimental observation of both the saddled and ruffled conformations of nickel dodecaphenylporphyrin. ${ }^{15}$

The acetylenyl-substituted metalloporphyrins considered here, $\mathrm{Y}_{4} \mathrm{TBP}$ complexes with $\mathrm{Y}=\mathrm{C} \equiv \mathrm{C}-\mathrm{SiMe}_{3}$ and $\mathrm{X}_{8} \mathrm{TAP}$ complexes, behave similar to dodecaphenylporphyrins in that they too exhibit essentially equienergetic saddled and ruffled conformations. We view this finding to be quite reasonable because acetylenyl and phenyl substituents are expected to exhibit similar minimum widths and similar Sterimol $\mathrm{B}_{1}$ parameters. Energetics considerations thus provide a rationale for the experimental observation of a ruffled platinum $\beta$ octaalkyl-meso-tetraacetylenylporphyrin. ${ }^{16}$

Table S1, Supporting Information shows key experimental structural data for selected saddled porphyrins relevant to this study. The reader may verify that the present calculations generally do an excellent job of reproducing the experimentally observed saddling distortions. For the full set of complexes studied, the degree of saddling (as measured by either $z_{\beta}$ or $\chi$, Figure 6) or ruffling (as measured by either $z_{\text {meso }}$ or $\psi$, Figure 7) also shows an excellent correlation with the Charton parameter and a somewhat worse correlation with Sterimol $B_{1}$.

\section{CONCLUSIONS}

Dispersion-corrected DFT calculations indicate a clear preference for the saddled conformation for the majority of $\mathrm{X}_{8} \mathrm{TPP}$ complexes, consistent with a large body of experimental data. For $\mathrm{X}_{8} \mathrm{TPP}$ complexes, where $\mathrm{X}=\mathrm{Ph}$ (i.e., dodecaphenylporphyrins), or $\mathrm{Y}_{4} \mathrm{TBP}$ complexes, where $\mathrm{Y}=\mathrm{C} \equiv \mathrm{C}$ $\mathrm{SiMe}_{3}$, as well as for $\mathrm{X}_{8} \mathrm{TAP}$ complexes, however, the saddled and ruffled conformations are found to be nearly equienergetic,
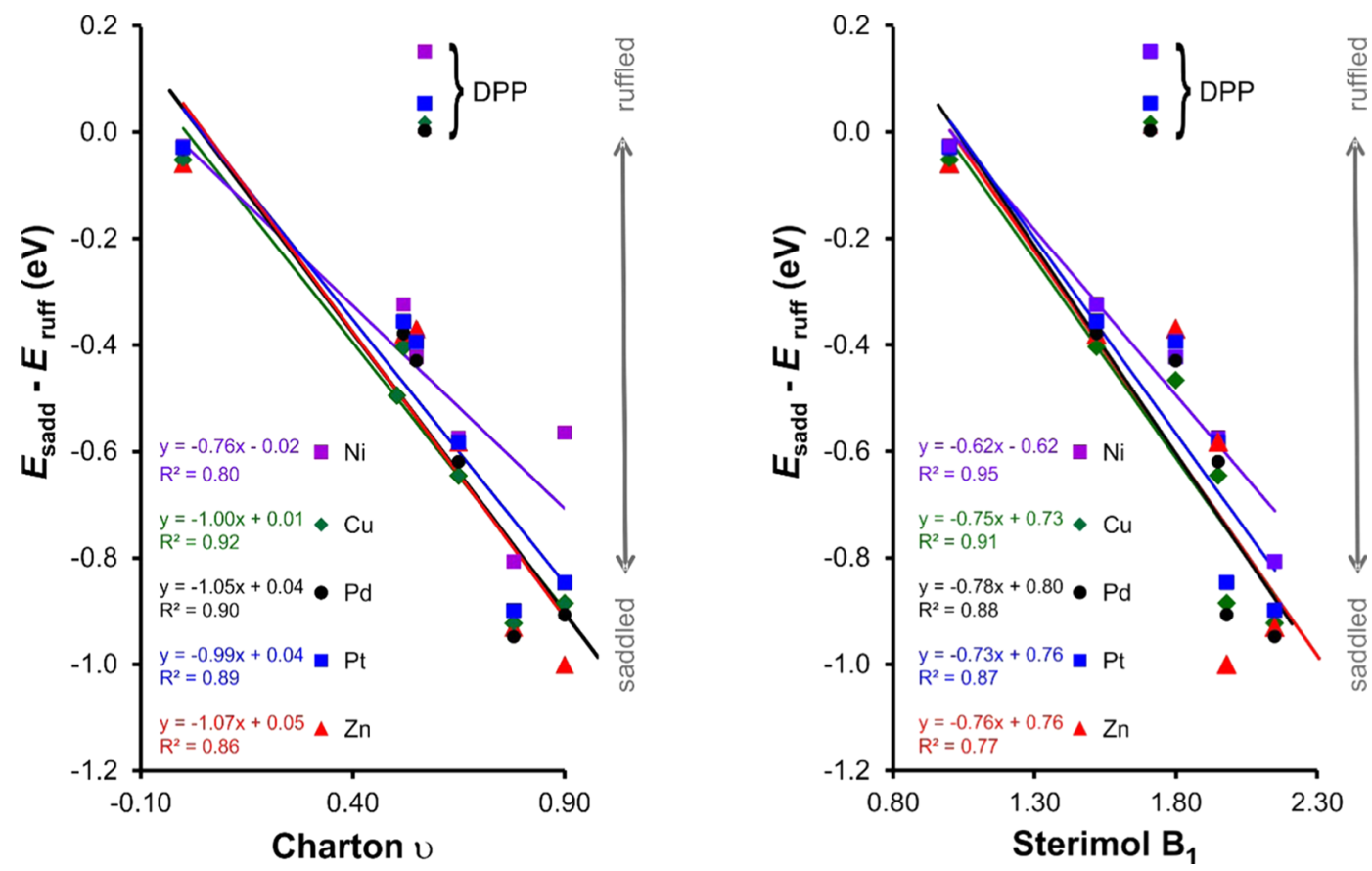

Figure 5. Energy difference $(\mathrm{eV})$ between saddled and ruffled conformations of $\mathrm{X}_{8} \mathrm{TPP}\left(\mathrm{X} \mathrm{Me}, \mathrm{Cl}, \mathrm{Br}, \mathrm{I}, \mathrm{CF}_{3}\right.$, or $\left.\mathrm{Ph}\right)$ complexes of different metal

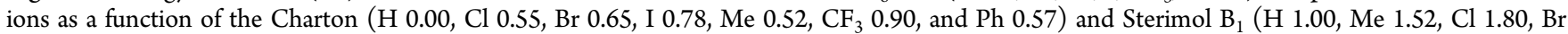
1.95, I 2.15, CF3 1.98, and Ph 1.71) steric parameters. 

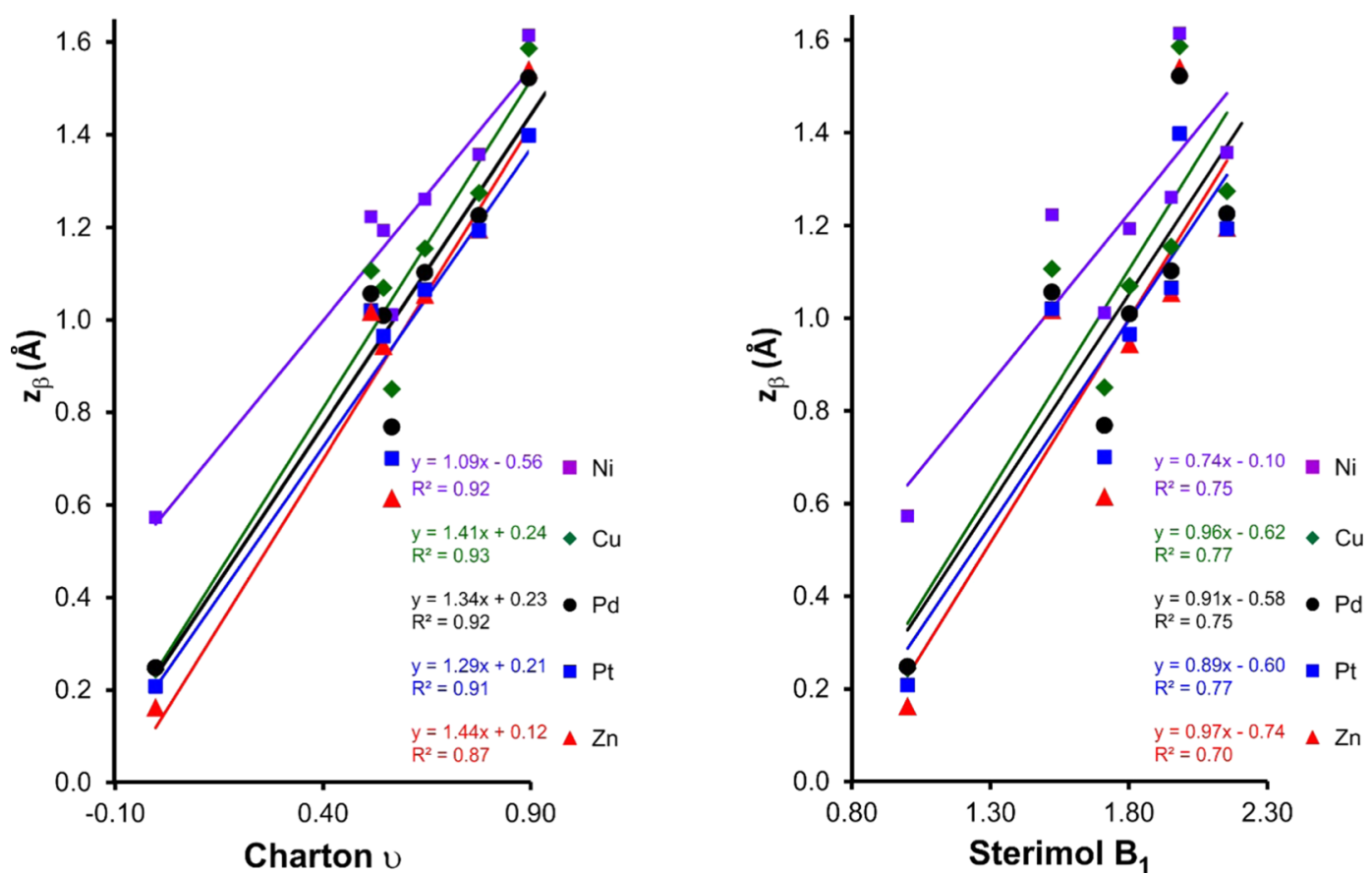

Figure 6. Degree of saddling $\left(z_{\beta}\right)$ of $\mathrm{X}_{8} \mathrm{TPP}\left(\mathrm{X} \mathrm{Me}, \mathrm{Cl}, \mathrm{Br}, \mathrm{I}, \mathrm{CF}_{3}\right.$, or $\left.\mathrm{Ph}\right)$ complexes of different metal ions as a function of the $\mathrm{Charton}(\mathrm{H} 0.00, \mathrm{Me}$ $0.52, \mathrm{Cl} 0.55, \mathrm{Ph} 0.57, \mathrm{Br} 0.65$, I 0.78, and $\left.\mathrm{CF}_{3} 0.90\right)$ and Sterimol $\mathrm{B}_{1}\left(\mathrm{H}\right.$ 1.00, Me 1.52, $\mathrm{Ph} \mathrm{1.71,} \mathrm{Cl} 1.80, \mathrm{Br} 1.95, \mathrm{I} 2.15$, and $\mathrm{CF}_{3}$ 1.98) steric parameters of X.
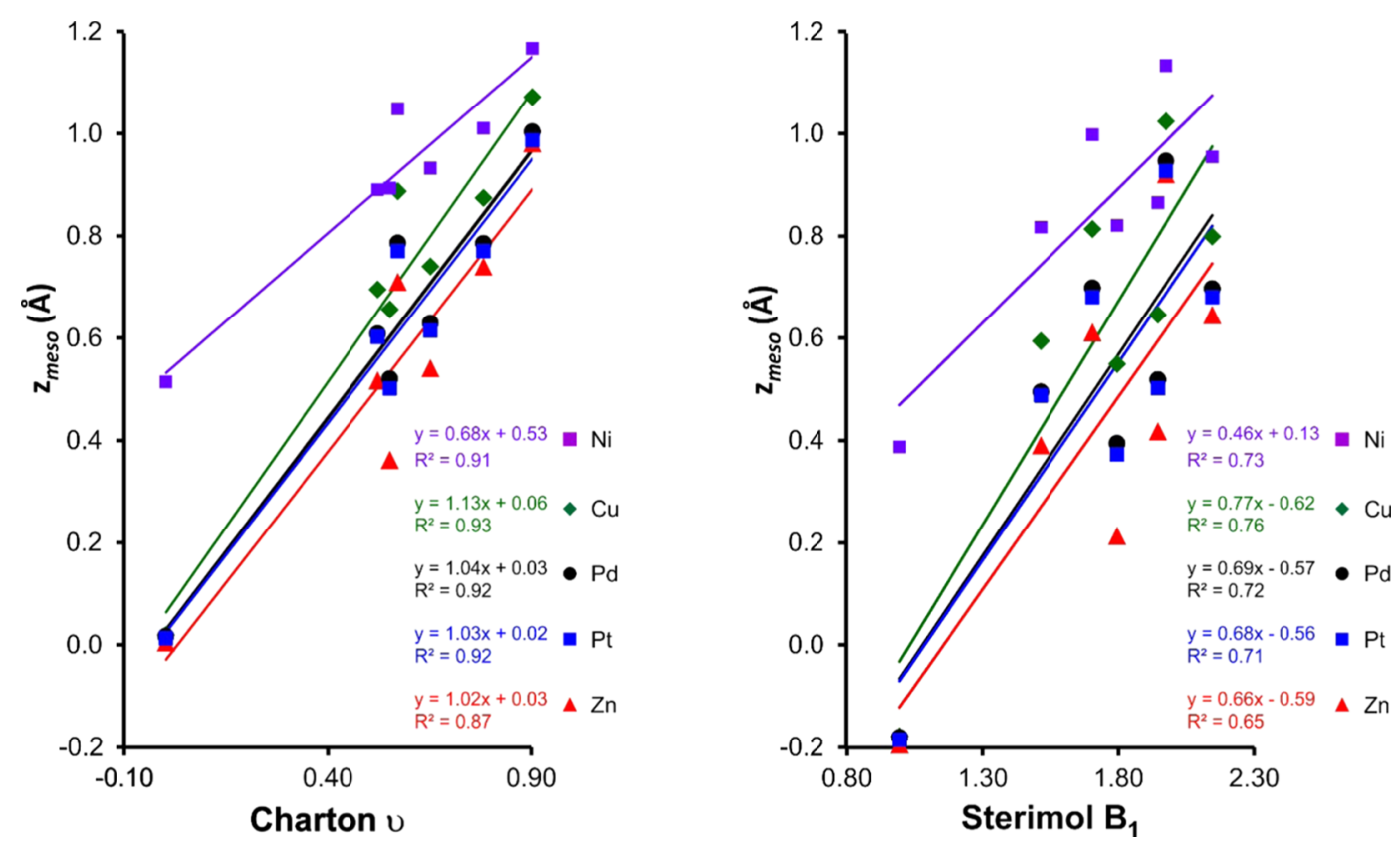

Figure 7. Degree of ruffling $\left(z_{\text {meso }}\right)$ of $\mathrm{X}_{8} \mathrm{TPP}\left(\mathrm{X} \mathrm{Me}, \mathrm{Cl}, \mathrm{Br}, \mathrm{I}, \mathrm{CF}_{3}\right.$, or $\left.\mathrm{Ph}\right)$ complexes of different metal ions as a function of the Charton $(\mathrm{H} 0.00$,

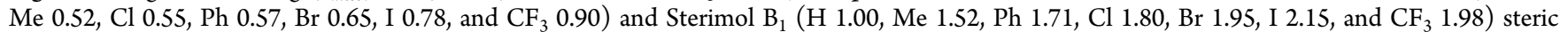
parameters of $\mathrm{X}$.

which explains the experimental observation of the ruffled conformation for a few dodecasubstituted metalloporphyrins. In general, the degree of saddling or ruffling exhibits a clear correlation with the Charton or Sterimol $B_{1}$ steric parameters of the substituents in question, except for dodecaphenylporphyrins and acetylenyl-substituted porphyrins. For these compounds, both the Charton and Sterimol $B_{1}$ parameters appear to greatly overestimate the actual steric effects exerted by phenyl and acetylenyl substituents.

\section{EXPERIMENTAL SECTION}

All DFT calculations were carried out with the ADF (Amsterdam Density Functional) 2013 program system, ${ }^{58}$ the BP86 functional in conjunction with Grimme's D3 ${ }^{59}$ dispersion corrections, Slater-type TZ2P basis sets, a fine mesh for numerical integration, and full geometry optimizations with tight convergence criteria. $\mathrm{D}_{2 \mathrm{~d}}$ or $\mathrm{D}_{2}$ symmetry constraints were used to derive the saddled and ruffled optimized conformations for each metalloporphryin. Free energy differences between the 
Table 1. Electronic Energy Differences (eV) between the Saddled and Ruffled Optimized Geometries, M-N Distances ( $\AA$ ), Ruffling $(\Psi)$ and Saddling $(\chi)$ Angles (deg), and $\alpha, \beta$ and meso Carbon Displacements $(\AA)$ above the Mean $\mathrm{N}_{4}$ Plane

\begin{tabular}{|c|c|c|c|c|c|c|c|c|c|}
\hline \multirow[b]{2}{*}{ complex } & \multirow[b]{2}{*}{ M } & \multicolumn{3}{|c|}{ ruffled } & \multicolumn{4}{|c|}{ saddled } & \multirow[b]{2}{*}{$E_{\text {sadd }}-E_{\text {ruf }}$} \\
\hline & & $(\mathrm{M}-\mathrm{N})_{\mathrm{av}}$ & $\Psi$ & $z_{\text {meso }}$ & $(\mathrm{M}-\mathrm{N})_{\mathrm{av}}$ & $\chi$ & $z_{\alpha}$ & $z_{\beta}$ & \\
\hline \multirow[t]{5}{*}{ TPP } & $\mathrm{Cu}$ & 2.008 & 1.1 & 0.019 & 2.012 & 15.7 & 0.075 & 0.244 & -0.05 \\
\hline & $\mathrm{Ni}$ & 1.933 & 31.3 & 0.514 & 1.945 & 14.7 & 0.239 & 0.573 & -0.03 \\
\hline & $\mathrm{Pd}$ & 2.025 & 1.0 & 0.017 & 2.027 & 13.6 & 0.083 & 0.248 & -0.03 \\
\hline & $\mathrm{Pt}$ & 2.024 & 0.7 & 0.013 & 2.026 & 11.3 & 0.070 & 0.208 & -0.03 \\
\hline & $\mathrm{Zn}$ & 2.043 & 0.3 & 0.005 & 2.048 & 16.3 & 0.033 & 0.163 & -0.06 \\
\hline \multirow[t]{5}{*}{$\mathrm{Me}_{8} \mathrm{TPP}$} & $\mathrm{Ni}$ & 1.890 & 56.0 & 0.890 & 1.903 & 36.0 & 0.507 & 1.223 & -0.32 \\
\hline & $\mathrm{Cu}$ & 1.979 & 43.0 & 0.695 & 1.987 & 44.9 & 0.429 & 1.106 & -0.40 \\
\hline & $\mathrm{Zn}$ & 2.040 & 31.5 & 0.517 & 2.033 & 45.4 & 0.384 & 1.018 & -0.38 \\
\hline & $\mathrm{Pd}$ & 2.014 & 37.5 & 0.608 & 2.012 & 43.5 & 0.407 & 1.056 & -0.38 \\
\hline & $\mathrm{Pt}$ & 2.015 & 36.9 & 0.602 & 2.010 & 39.0 & 0.401 & 1.020 & -0.36 \\
\hline \multirow[t]{5}{*}{$\mathrm{Cl}_{8} \mathrm{TPP}$} & $\mathrm{Ni}$ & 1.894 & 56.0 & 0.893 & 1.912 & 35.5 & 0.492 & 1.193 & -0.42 \\
\hline & $\mathrm{Cu}$ & 1.990 & 40.6 & 0.656 & 1.996 & 44.0 & 0.412 & 1.069 & -0.47 \\
\hline & $\mathrm{Zn}$ & 2.060 & 22.1 & 0.362 & 2.037 & 38.3 & 0.365 & 0.944 & -0.37 \\
\hline & $\mathrm{Pd}$ & 2.027 & 32.1 & 0.520 & 2.018 & 41.7 & 0.388 & 1.009 & -0.43 \\
\hline & $\mathrm{Pt}$ & 2.028 & 30.8 & 0.501 & 2.015 & 35.7 & 0.381 & 0.965 & -0.39 \\
\hline \multirow[t]{5}{*}{$\mathrm{Br}_{8} \mathrm{TPP}$} & $\mathrm{Ni}$ & 1.888 & 59.1 & 0.932 & 1.906 & 38.2 & 0.521 & 1.261 & -0.57 \\
\hline & $\mathrm{Cu}$ & 1.979 & 46.2 & 0.740 & 1.992 & 48.4 & 0.446 & 1.154 & -0.65 \\
\hline & $\mathrm{Zn}$ & 2.045 & 33.4 & 0.541 & 2.034 & 44.2 & 0.407 & 1.055 & -0.58 \\
\hline & $\mathrm{Pd}$ & 2.019 & 39.2 & 0.629 & 2.016 & 46.5 & 0.424 & 1.102 & -0.62 \\
\hline & $\mathrm{Pt}$ & 2.020 & 38.2 & 0.614 & 2.011 & 40.6 & 0.420 & 1.065 & -0.58 \\
\hline \multirow[t]{5}{*}{$\mathrm{I}_{8} \mathrm{TPP}$} & $\mathrm{Ni}$ & 1.873 & 64.7 & 1.010 & 1.897 & 44.3 & 0.557 & 1.357 & -0.81 \\
\hline & $\mathrm{Cu}$ & 1.955 & 55.3 & 0.874 & 1.987 & 56.8 & 0.490 & 1.274 & -0.92 \\
\hline & $\mathrm{Zn}$ & 2.017 & 46.3 & 0.740 & 2.028 & 54.2 & 0.457 & 1.196 & -0.93 \\
\hline & $\mathrm{Pd}$ & 1.999 & 49.4 & 0.785 & 2.011 & 54.7 & 0.470 & 1.225 & -0.95 \\
\hline & $\mathrm{Pt}$ & 2.002 & 48.3 & 0.770 & 2.005 & 48.5 & 0.468 & 1.193 & -0.90 \\
\hline \multirow[t]{5}{*}{$\left(\mathrm{CF}_{3}\right)_{8} \mathrm{TPP}$} & $\mathrm{Ni}$ & 1.842 & 73.8 & 1.167 & 1.880 & 67.9 & 0.652 & 1.615 & -0.56 \\
\hline & $\mathrm{Cu}$ & 1.919 & 67.0 & 1.071 & 1.984 & 88.1 & 0.599 & 1.586 & -0.88 \\
\hline & $\mathrm{Zn}$ & 1.977 & 60.8 & 0.981 & 2.026 & 87.7 & 0.575 & 1.541 & -1.00 \\
\hline & $\mathrm{Pd}$ & 1.966 & 62.2 & 1.003 & 2.000 & 80.1 & 0.580 & 1.522 & -0.91 \\
\hline & $\mathrm{Pt}$ & 1.973 & 61.0 & 0.986 & 1.993 & 62.7 & 0.547 & 1.398 & -0.85 \\
\hline \multirow[t]{5}{*}{ DPP } & $\mathrm{Ni}$ & 1.860 & 64.9 & 1.048 & 1.933 & 25.9 & 0.423 & 1.011 & 0.15 \\
\hline & $\mathrm{Cu}$ & 1.946 & 53.4 & 0.887 & 1.995 & 30.3 & 0.336 & 0.850 & 0.02 \\
\hline & $\mathrm{Zn}$ & 2.013 & 41.2 & 0.710 & 2.048 & 22.9 & 0.240 & 0.615 & 0.01 \\
\hline & $\mathrm{Pd}$ & 1.990 & 46.5 & 0.786 & 2.024 & 26.6 & 0.536 & 0.768 & 0.00 \\
\hline & $\mathrm{Pt}$ & 1.994 & 45.3 & 0.770 & 2.023 & 22.0 & 0.283 & 0.700 & 0.05 \\
\hline \multirow[t]{5}{*}{$\mathrm{Ph}_{4} \mathrm{TBP}$} & $\mathrm{Ni}$ & 1.889 & 60.2 & 0.946 & 1.928 & 25.2 & 0.485 & 1.132 & -0.15 \\
\hline & $\mathrm{Cu}$ & 1.983 & 47.3 & 0.753 & 1.998 & 28.6 & 0.415 & 1.003 & -0.25 \\
\hline & $\mathrm{Zn}$ & 2.049 & 34.9 & 0.563 & 2.045 & 26.5 & 0.368 & 0.894 & -0.26 \\
\hline & $\mathrm{Pd}$ & 2.018 & 41.6 & 0.665 & 2.024 & 31.0 & 0.385 & 0.954 & -0.24 \\
\hline & $\mathrm{Pt}$ & 2.018 & 40.8 & 0.654 & 2.022 & 28.3 & 0.379 & 0.927 & -0.24 \\
\hline \multirow[t]{5}{*}{$\mathrm{A}_{4} \mathrm{TBP}$} & $\mathrm{Ni}$ & 1.890 & 60.9 & 1.005 & 1.893 & 13.5 & 0.356 & 0.808 & 0.02 \\
\hline & $\mathrm{Cu}$ & 1.987 & 46.9 & 0.805 & 1.987 & 20.0 & 0.417 & 0.960 & -0.03 \\
\hline & $\mathrm{Zn}$ & 2.059 & 31.5 & 0.576 & 2.039 & 21.0 & 0.412 & 0.949 & -0.10 \\
\hline & $\mathrm{Pd}$ & 2.021 & 40.8 & 0.716 & 2.020 & 24.3 & 0.399 & 0.944 & -0.02 \\
\hline & $\mathrm{Pt}$ & 2.021 & 40.4 & 0.711 & 2.019 & 22.6 & 0.391 & 0.918 & -0.01 \\
\hline \multirow[t]{5}{*}{$\mathrm{Me}_{8} \mathrm{TAP}$} & $\mathrm{Ni}$ & 1.890 & 55.7 & 0.931 & 1.903 & 21.5 & 0.522 & 1.184 & 0.18 \\
\hline & $\mathrm{Cu}$ & 1.981 & 41.8 & 0.731 & 1.982 & 26.1 & 0.442 & 1.038 & 0.05 \\
\hline & $\mathrm{Zn}$ & 2.047 & 27.1 & 0.506 & 2.031 & 25.9 & 0.390 & 0.929 & 0.00 \\
\hline & $\mathrm{Pd}$ & 2.016 & 35.6 & 0.636 & 2.014 & 28.7 & 0.404 & 0.974 & 0.07 \\
\hline & $\mathrm{Pt}$ & 2.016 & 35.4 & 0.636 & 2.015 & 26.4 & 0.395 & 0.943 & 0.08 \\
\hline \multirow[t]{5}{*}{$\mathrm{Br}_{8} \mathrm{TAP}$} & $\mathrm{Ni}$ & 1.885 & 59.8 & 1.019 & 1.900 & 28.0 & 0.568 & 1.306 & 0.25 \\
\hline & $\mathrm{Cu}$ & 1.975 & 47.4 & 0.845 & 1.979 & 29.3 & 0.431 & 1.036 & 0.03 \\
\hline & $\mathrm{Zn}$ & 2.040 & 35.0 & 0.661 & 2.027 & 31.9 & 0.455 & 1.085 & -0.01 \\
\hline & $\mathrm{Pd}$ & 2.013 & 41.1 & 0.752 & 2.015 & 35.7 & 0.457 & 1.110 & 0.06 \\
\hline & $\mathrm{Pt}$ & 2.013 & 40.5 & 0.745 & 2.013 & 31.5 & 0.448 & 1.073 & 0.10 \\
\hline
\end{tabular}

two conformations were calculated for several selected complexes and were found to be very similar (to well within
$0.1 \mathrm{eV}$ ) to the electronic energy differences, and accordingly only the latter have been reported in Table 1. 


\section{ASSOCIATED CONTENT}

\section{S Supporting Information}

The Supporting Information is available free of charge on the ACS Publications website at DOI: 10.1021/acsomega.7b01004. DFT-optimized coordinates (232 pages) (PDF)

\section{AUTHOR INFORMATION}

\section{Corresponding Authors}

*E-mail: conradj@ufs.ac.za (J.C.).

*E-mail: abhik.ghosh@uit.no (A.G.).

ORCID

Abhik Ghosh: 0000-0003-1161-6364

Notes

The authors declare no competing financial interest.

\section{ACKNOWLEDGMENTS}

This work was supported by grants 231086 and 262229 of the Research Council of Norway (AG) and by the National Research Fund of the Republic of South Africa (JC).

\section{REFERENCES}

(1) Shelnutt, J. A.; Song, X.-Z.; Ma, J.-G.; Jia, S.-L.; Jentzen, W.; Medforth, C. J.; Medforth, C. J. Nonplanar Porphyrins and Their Significance in Proteins. Chem. Soc. Rev. 1998, 27, 31-42.

(2) Golubchikov, O. A.; Pukhovskaya, S. G.; Kuvshinova, E. M. Structures and Properties of Spatially Distorted Porphyrins. Russ. Chem. Rev. 2005, 74, 249-264.

(3) Kleingardner, J. G.; Bren, K. L. Acc. Chem. Res. 2015, 48, 18451852 .

(4) Brennan, T. D.; Scheidt, W. R.; Shelnutt, J. A. J. Am. Chem. Soc. 1988, 110, 3919.

(5) Meyer, E. F., Jr. Acta Crystallogr., Sect. B: Struct. Crystallogr. Cryst. Chem. 1972, 28, 2162.

(6) Jia, S.-L.; Jentzen, W.; Shang, M.; Song, X.-Z.; Ma, J.-G.; Scheidt, W. R.; Shelnutt, J. A. Axial Coordination and Conformational Heterogeneity of Nickel(II) Tetraphenylporphyrin Complexes with Nitrogenous Bases. Inorg. Chem. 1998, 37, 4402-4412.

(7) Kozlowski, P. M.; Rush, T. S., III; Jarzecki, A. A.; Zgierski, M.; Chase, B.; Piffat, C. A.; Ye, B.-H.; Li, Z.-Y.; Pulay, P.; Spiro, T. G. DFT-SQM Force Field for Nickel Porphine: Intrinsic Ruffling. J. Phys. Chem. A 1999, 103, 1357-1366.

(8) Rush, T. S., III; Kozlowski, P. M.; Piffat, C. A.; Kumble, R; Zgierski, M.; Spiro, T. G. Computational Modeling of Metalloporphyrin Structure and Vibrational Spectra: Porphyrin Ruffling in NiTPP. J. Phys. Chem. B 2000, 104, 5020-5034.

(9) Nakamura, M. Electronic Structures of Highly Deformed Iron(III) Porphyrin Complexes. Coord. Chem. Rev. 2006, 250, 2271-2294.

(10) Senge, M. O.; Bischoff, I.; Nelson, N. Y.; Smith, K. M. Synthesis, reactivity and structural chemistry of 5,10,15,20-tetraalkylporphyrins. J. Porphyrins Phthalocyanines 1999, 3, 99-116.

(11) Ema, T.; Senge, M. O.; Nelson, N. Y.; Ogoshi, H.; Smith, K. M. $5,10,15,20$-Tetra-tert-butylporphyrin and Its Remarkable Reactivity in the 5- and 15-Positions. Angew. Chem., Int. Ed. 1994, 33, 1879-1881 (CSD reference code HETDAL).

(12) Senge, M. O.; Ema, T.; Smith, K. M. Crystal structure of a remarkably ruffled nonplanar porphyrin (pyridine) $[5,10,15,20$-tetra(tert-butyl)porphyrinato]zinc(II). J. Chem. Soc., Chem. Commun. 1995, 733-734 (CSD reference code ZIJDAX).

(13) Barkigia, K. M.; Nurco, D. J.; Renner, M. W.; Melamed, D.; Smith, K. M.; Fajer, J. Multiconformational Surfaces in Porphyrins: Previews into Excited-State Landscapes. J. Phys. Chem. B 1998, 102, $322-326$.

(14) Nurco, D. J.; Medforth, C. J.; Forsyth, T. P.; Olmstead, M. M.; Smith, K. M. Conformational Flexibility in Dodecasubstituted
Porphyrins. J. Am. Chem. Soc. 1996, 118, 10918-10919 (CSD reference code TEZXEB, TEZXIF).

(15) Drain, C. M.; Kirmaier, C.; Medforth, C. J.; Nurco, D. J.; Smith, K. M.; Holten, D. Dynamic Photophysical Properties of Conformationally Distorted Nickel Porphyrins. 1. Nickel(II) Dodecaphenylporphyrin. J. Phys. Chem. 1996, 100, 11984-11993.

(16) Krivokapic, A.; Cowley, A. R.; Anderson, H. L. Contracted and Expanded meso-Alkynyl Porphyrinoids: from Triphyrin to Hexaphyrin. J. Org. Chem. 2003, 68, 1089-1096 (CSD reference code LUTYOO, LUTYII).

(17) Vangberg, T.; Ghosh, A. A First-Principles Quantum Chemical Analysis of the Factors Controlling Ruffling Deformations of Porphyrins: Insights from the Molecular Structures and Potential Energy Surfaces of Silicon, Phosphorus, Germanium, and Arsenic Porphyrins and of a Peroxidase Compound I Model. J. Am. Chem. Soc. 1999, 121, 12154-12160.

(18) Conradie, J.; Wondimagegn, T.; Ghosh, A. Spin States at a Tipping Point: What Determines the $\mathrm{d}_{\mathrm{z} 2}{ }^{1}$ Ground State of Nickel(III) Tetra(tbutyl)porphyrin Dicyanide? J. Phys. Chem. B 2008, 112, 10531056.

(19) Ghosh, A.; Halvorsen, I.; Nilsen, H. J.; Steene, E.; Wondimagegn, T.; Lie, R.; Van caemelbecke, E.; Guo, N.; Ou, Z.; Kadish, K. M. Electrochemistry of Nickel and Copper $\beta$ Octahalogeno-meso-tetraarylporphyrins. Evidence for Important Role Played by Saddling-Induced Metal $\left(\mathrm{d}_{\mathrm{xz}-\mathrm{y} 2}\right)$-Porphyrin(" $\mathrm{a}_{2 \mathrm{u}}$ ") Orbital Interactions. J. Phys. Chem. B 2001, 105, 8120-8124.

(20) Wondimagegn, T.; Ghosh, A. Ruffling Deformations of Nickel(II) and Zinc(II) Hydroporphyrin and Chlorophin Complexes: Implications for $\mathrm{F}_{430}$, the Nickel Tetrapyrrole Cofactor of Methylcoenzyme M Reductase. J. Phys. Chem. B 2000, 104, 10858-10862.

(21) Ryeng, H.; Gonzalez, E.; Ghosh, A. DFT at Its Best: Metalversus Ligand-Centered Reduction in Nickel Hydroporphyrins. J. Phys. Chem. B 2008, 112, 15158-15173.

(22) Sharma, M.; Ticho, A. L.; Samankumara, L.; Zeller, M.; Brückner, C. Conformational Landscapes of Metal(II) Porphyrinato, Chlorinato, and Morpholinochlorinato Complexes. Inorg. Chem. 2017, 56, 11490-11502.

(23) Guberman-Pfeffer, M. J.; Greco, J. A.; Samankumara, L. P.; Zeller, M.; Birge, R. R.; Gascón, J. A.; Brückner, C. Bacteriochlorins with a Twist: Discovery of a Unique Mechanism to Red-Shift the Optical Spectra of Bacteriochlorins. J. Am. Chem. Soc. 2017, 139, 548560

(24) Wondimagegn, T.; Ghosh, A. Conformational Flexibility of meso-Tetrakis(perfluoroalkyl)porphyrins: Energetics of Ruffling versus Saddling. J. Phys. Chem. A 2000, 104, 4606-4608.

(25) Ryeng, H.; Ghosh, A. Do Nonplanar Distortions of Porphyrins Bring about Strongly Red-Shifted Electronic Spectra? Controversy, Consensus, New Developments, and Relevance to Chelatases. J. Am. Chem. Soc. 2002, 124, 8099-8103.

(26) Wasbotten, I. H.; Conradie, J. H.; Ghosh, A. Electronic Absorption and Resonance Raman Signatures of Hyperporphyrins and Nonplanar Porphyrins. J. Phys. Chem. B 2003, 107, 3613-3623.

(27) Lebedev, A. Y.; Filatov, M. A.; Cheprakov, A. V.; Vinogradov, S. A. Effects of Structural Deformations on Optical Properties of Tetrabenzoporphyrins: Free-Bases and Pd Complexes. J. Phys. Chem. A 2008, 112, 7723-7733.

(28) Fukuzumi, S.; Kojima, T. Nanostructures and Electron-Transfer Functions of Nonplanar Porphyrins. In Organic Nanomaterials: Synthesis, Characterization, and Device Applications; Torres, T.; Bottari, G., Eds.; Wiley: Hoboken, NJ, 2013; Ch. 6.

(29) Shahroosvand, H.; Zakavi, S.; Sousaraeia, A.; Eskandaria, M. Saddle-Shaped Porphyrins for Dye-Densitized Solar Cells: New Insight into the Relationship Between Nonplanarity and Photovoltaic Properties. Phys. Chem. Chem. Phys. 2015, 17, 6347-6358.

(30) Barkigia, K. M.; Berber, M. D.; Fajer, J.; Medforth, C. J.; Renner, M. W.; Smith, K. M. Nonplanar porphyrins. X-ray Structures of $(2,3,7,8,12,13,17,18$-Octaethyl- and -octamethyl-5,10,15,20tetraphenylporphinato)zinc(II). J. Am. Chem. Soc. 1990, 112, 88518857. 
(31) Sparks, L. D.; Medforth, C. J.; Park, M.-S.; Chamberlain, J. R.; Ondrias, M. R.; Senge, M. O.; Smith, K. M.; Shelnutt, J. A. Metal Dependence of the Nonplanar Distortion of Octaalkyltetraphenylporphyrins. J. Am. Chem. Soc. 1993, 115, 581-592.

(32) Senge, M. O.; Medforth, C. J.; Sparks, L. D.; Shelnutt, J. A.; Smith, K. M. A Planar Dodecasubstituted Porphyrin. Inorg. Chem. 1993, 32, 1716-1723.

(33) Schaefer, W. P.; Hodge, J. A.; Hughes, M. E.; Gray, H. B.; Lyons, J. E.; Ellis, P. E., Jr.; Wagner, R. W. Copper(II) tetrakis(pentafluorophenyl)- $\beta$-octachloroporphyrin. Acta Crystallogr., Sect. C: Cryst. Struct. Commun. 1993, 49, 1342-1345.

(34) Birnbaum, E. R.; Hodge, J. A.; Grinstaff, M. W.; Schaefer, W. P.; Henling, L.; Labinger, J. A.; Bercaw, J. E.; Gray, H. B. ${ }^{19}$ F NMR Spectra and Structures of Halogenated Porphyrins. Inorg. Chem. 1995, 34, 3625-3632.

(35) Spyroulias, G. A.; Despotopoulos, A. P.; Raptopoulou, C. P.; Terzis, A.; de Montauzon, D.; Poilblanc, R.; Coutsolelos, A. G. Comparative Study of Structure-Properties Relationship for Novel $\beta$ Halogenated Lanthanide Porphyrins and Their Nickel and Free Bases Precursors, as a Function of Number and Nature of Halogens Atoms. Inorg. Chem. 2002, 41, 2648-2659.

(36) Kumar, R.; Chaudhria, N.; Sankar, M. Ratiometric and Colorimetric "Naked Eye" Selective Detection of $\mathrm{CN}^{-}$Ions by Electron Deficient Ni(II) Porphyrins and Their Reversibility Studies. Dalton Trans. 2015, 44, 9149-9157.

(37) Marsh, R. E.; Schaefer, W. P.; Hodge, J. A.; Hughes, M. E.; Gray, H. B.; Lyons, J. E.; Ellis Jnr, P. E. A highly solvated zinc(II) tetrakis(pentafluorophenyl)- $\beta$-octabromoporphyrin. Acta Crystallogr., Sect. C: Cryst. Struct. Commun. 1993, 49, 1339-1342 (CSD reference code LALRIZ).

(38) Henling, L. M.; Schaefer, W. P.; Hodge, J. A.; Hughes, M. E.; Gray, H. B.; Lyons, J. E.; Ellis Jnr, P. E. Copper(II) and nickel(II) octabromo-tetrakis(pentafluorophenyl)porphyrin complexes. Acta Crystallogr., Sect. C: Cryst. Struct. Commun. 1993, 49, 1743-1747 (CSD reference code LATSEE, PAHKOY01).

(39) Mandon, D.; Ochenbein, P.; Fischer, J.; Weiss, R.; Jayaraj, K.; Austin, R. N.; Gold, A.; White, P. S.; Brigaud, O. $\beta$-Halogenatedpyrrole porphyrins. Molecular structures of 2,3,7,8,12,13,17,18octabromo-5,10,15,20-tetramesitylporphyrin, nickel(II) 2,3,7,8,12,13,17,18-octabromo-5,10,15,20-tetramesitylporphyrin, and nickel(II) 2,3,7,8,12,13,17,18-octabromo-5,10,15,20-tetrakis(pentafluorophenyl)porphyrin. Inorg. Chem. 1992, 31, 2044-2049 (CSD reference code PAHKIS, PAHKOY).

(40) Medforth, C. J.; Senge, M. O.; Smith, K. M.; Sparks, L. D.; Shelnutt, J. A. Nonplanar distortion modes for highly substituted porphyrins. J. Am. Chem. Soc. 1992, 114, 9859-9869 (CSD reference code LADGIG).

(41) Ishizuka, T.; Sankara, M.; Kojima, T. Control of the spatial arrangements of supramolecular networks based on saddle-distorted porphyrins by intermolecular hydrogen bonding. Dalton Trans. 2013, 42, 16073-16079 (CSD reference code ODIPIC).

(42) Thomassen, I. K.; Vazquez-Lima, H.; Gagnon, K. J.; Ghosh, A. Octaiodoporphyrin. Inorg. Chem. 2015, 54, 11493-11497 (CSD reference code JUZQIG, JUZQEC).

(43) Liu, C.; Chen, Q-Y. Fluoroalkylation of Porphyrins: A Facile Synthesis of Trifluoromethylated Porphyrins by a Palladium-Catalyzed Cross-Coupling Reaction. Eur. J. Org. Chem. 2005, 2005, 3680-3686 (CSD reference code TAWVOD).

(44) Sugawara, S.; Hirata, Y.; Kojima, S.; Yamamoto, Y.; Miyazaki, E.; Takimiya, K.; Matsukawa, S.; Hashizume, D.; Mack, J.; Kobayashi, N.; Fu, Z.; Kadish, K. M.; Sung, Y. M.; Kim, K. S.; Kim, D. Synthesis, Characterization, and Spectroscopic Analysis of Antiaromatic Benzofused Metalloporphyrins. Chem. - Eur. J. 2012, 18, 3566-3581.

(45) Ongayi, O.; Fronczek, F. R.; Vicente, M. G. H. Benzoylbiliverdins from Chemical Oxidation of Dodecasubstituted Porphyrins. Chem. Commun. 2003, 2298-2299.

(46) Barkigia, K. M.; Renner, M. W.; Furenlid, L. R.; Medforth, C. J.; Smith, K. M.; Fajer, J. Crystallographic and EXAFS studies of conformationally designed nonplanar nickel(II) porphyrins. J. Am. Chem. Soc. 1993, 115, 3627-3635 (CSD reference code SULDEI).

(47) Borek, C.; Hanson, K.; Djurovich, P. I.; Thompson, M. E.; Aznavour, K.; Bau, R.; Sun, Y.; Forrest, S. R.; Brooks, J.; Michalski, L.; Brown, J. Highly Efficient, Near-Infrared Electrophosphorescence from a Pt-Metalloporphyrin Complex. Angew. Chem., Int. Ed. 2007, 46, 1109-1112 (CSD reference code SEWCUT).

(48) Charton, M. Steric effects. I. Esterification and acid-catalyzed hydrolysis of esters. J. Am. Chem. Soc. 1975, 97, 1552-1556.

(49) Charton, M. Steric effects. 7. Additional V constants. J. Org. Chem. 1976, 41, 2217-2220.

(50) Charton, M. The Upsilon Steric Parameter - Definition and Determination. Top. Curr. Chem. 1983, 114, 57-91.

(51) Charton's steric parameters $v_{\mathrm{X}}$ are derived from van der Waals radii $(\AA)$ of a substituent $\mathrm{X}$ via the equation $v_{\mathrm{X}}=r_{\mathrm{X}}-r_{\mathrm{H}}=r_{\mathrm{X}}-1.20$, where $r_{\mathrm{X}}$ and $r_{\mathrm{H}}$ are the van der Waals radii of $\mathrm{X}$ and hydrogen, respectively. For an unsymmetrical substituent $\mathrm{X}, r_{\mathrm{X}}$ is chosen as the minimum van der Waals radius.

(52) Verloop, A. The Use of Linear Free Energy Parameters and Other Experimental Constants in Structure-Activity Studies. In Drug Design; Ariens, E. J., Ed.; Academic: New York, 1972; Vol. 3, pp 133187.

(53) Verloop, A.; Hoogenstraaten, W.; Tipker, J. Development and Application of New Steric Substituent Parameters. In Drug Design; Ariens, E. J., Ed.; Academic: New York, 1976; Vol. 7, pp 165-207.

(54) Verloop, A.; Tipker, J. Use of Linear Free Energy Related and Other Parameters in the Study of Fungicidal Selectivity. Pestic. Sci. 1976, 7, 379-390.

(55) Verloop, A.; Tipker, J. A Comparative Study of New parameters in Drug Design. In Biological Activity and Chemical Structure; Buisman, J. A. K., Ed.; Elsevier: Amsterdam, 1977; pp 63-81.

(56) For a review, see: Harper, K. C.; Bess, E. N.; Sigman, M. S. Multidimensional steric parameters in the analysis of asymmetric catalytic reactions. Nat. Chem. 2012, 4, 366-374.

(57) Verloop's current steric parameters contain three subparameters, two width parameters $B_{1}$ and $B_{5}$ and a length parameter $L$. The $B_{1}$ parameter describes the minimum profile width of the substituent from the primary bond axis and the $B_{5}$ parameter describes the maximum width from the same axis.

(58) The ADF program system uses methods described in: Velde, G. t.; Bickelhaupt, F. M.; Baerends, E. J.; Guerra, C. F.; van Gisbergen, S. J. A.; Snijders, J. G.; Ziegler, T. J. Comput. Chem. 2001, 22, 931-967. For additional details, including the procedure for calculation of Gibbs free energies, see the ADF program manual: http://www.scm.com/ $\mathrm{ADF} /$.

(59) Grimme, S.; Anthony, J.; Ehrlich, S.; Krieg, H. A Consistent and Accurate $A b$ Initio Parametrization of Density Functional Dispersion Correction (DFT-D) for the 94 Elements H-Pu. J. Chem. Phys. 2010, 132, No. 154104. 